\title{
Könyvszemle
}

SIPOS JÚLIA GONDOZÁSÁBAN

\section{A LEGENDÁS TUDÓS, SZENT-GYÖRGYI ALBERT ÖNÉLETRAJZI ÉRTEKEZÉSEI}

A Goodwill Pharma az Egészségért Alapítvány kiadásában megjelent $A$ legendás tudós, Szent-Györgyi Albert önéletrajzi értekezései címü könyve (szerkesztette, fordította és jegyzetelte Tasiné Csúcs Ildikó és Tasi Domonkos Attila) magyar és angol nyelven elsősorban a személyiség és az alkotás viszonyáról szól. Megejtő őszinteséggel ad közre számos gondolatot a kreatív intellektusról; a szerző élete egyes fejezeteinek értelmezése is rendre e körül forog. A mottónak választott idézet - „Ha letérítjük a fiatalokat a tudomány útjáról, akkor saját magunkat fosztjuk meg a jövőtől" - pedig arról, hogy Szent-Györgyi egész életében a fiatalokra összpontosított, és emiatt maradt idősebb éveiben is fiatal.

Aki különböző életkorokban ír önéletrajzi visszaemlékezéseket még akkor is sokféleképpen teszi azt, ha az életének egyes eseményeit felidéző és azokat értékelő gondolatai a különböző írásokban vissza-visszatérnek. Szent-Györgyi 1893-ban született. Az ebben a könyvben közölt írások 1961 és 1976 között jelentek meg eredetileg angolul (magyar fordításban: Egy tudós visszaemlékezései [1976], A tudományos alkotókészségről [1962], Visszatekintés [1971], Elhagyatottan a 20. században [1963] címmel). Az életrajzi összefoglalók nagyon sok történelmi érdekességet, értelmezést és adatot is tartalmaznak, amelyek mind a magyar történelemírás, mind az egyetemes tudománytörténet forrásai lehetnek. Tudománytörténeti szempontból a múlt század húszas-harmincas éveinek nyitottsága, személyi kapcsolatai különösen érdekesek. Számomra, aki a budapesti Puskin utcában éltem le életem jelentős részét, például igen elgondolkoztató, hogy 1945-ben ott körülbelül hatvan munkatárssal hozott létre közvetlen a második világháború után egy intézetet. Ez az akkori viszonyok között hatalmas intézeti létszámnak számít, és 1948-ra az eredeti intézet legtöbb diplomás munkatársa Szent-Györgyivel emigrált. Az akkori körülményekről alig van hiteles forrás.

A könyvben közölt írásokban megjelenő gondolatok jelentős része időtlen; az írások sorrendje sem időrendi. Gondolataival Szent-Györgyi számos esetben mintegy bekapcsolódik a tudományos és nem tudományos közvéleményt jelenleg is foglalkoztató, aktuális vitákba, így többek között a kutatásról, a kutatás jelle- 
géről, az alkotókészségről, a tudományos teljesítmények összehasonlíthatóságáról, értékeléséről, mindenekelőtt a kutató tudós személyiségérőll.

A tudománnyal foglalkozók számára örök ellentét feszül a demokrácia és a meritokrácia között. „Az emberiség fejlődése [...] egy viszonylag kisszámú kreatív csoport tevékenységének eredménye, olyanoké, akik nagyot alkottak a múvészetben, tudományban vagy más területén az emberi igyekezetnek..." Szent-Györgyit a kutatók, tudósok motivációja, személyiségjegyei foglalkoztatják. A kiemelkedő egyéniség kérdésköre sokféle módon tér vissza a különböző írásokban: „,..a kiemelkedő tehetségek fejlődését bizonyos mértékben akadályozzák a demokrácia azon nem ideillő eszméi, amelyek szerint mindannyian egyenlők vagyunk. A természet nem demokratikus, már ami az értelmet illeti..." Ezek a gondolatok a mai elitellenes világban nem mindenkinek hangzanak jól. A tehetséggondozás helyes gyakorlata, annak ismert problémái, a kiemelkedő intellektusú emberek kezelése és a magukat zseninek tartó kutatók saját maguknak és másoknak okozott traumái ismertek. Ebben a mérték és a helyes arányok kialakítása a tudományos kutatóhelyekben zajló élet gyakori problémája. A szerző szembemegy az ismert szemlélettel, hogy „,...a zseninek nincs szüksége segítségre, előbb-utóbb utat tör magának. Én (Szent-Györgyi) attól tartok, hogy segítség nélkül inkább a nyakukat törik, hisz a kiemelkedő intellektus sokszor magas érzékenységgel párosul”. Ezért az alapgondnak inkább azt tekinti, hogy „...a zsenik bizonyos számban mindig jelen vannak, csak elkallódnak..."

E kérdéskör szorosan kapcsolódik a tudományos teljesítmény megítélésének megoldatlan kérdéseihez. „A tendencia az, hogy a kiválóságot számokkal helyettesítjük, a minőséget pedig mennyiséggel." Ennél találóbban ezt számomra még senki nem fogalmazta meg. A már említett fiatal tehetségekkel kapcsolatban így ír: „...fiataljainkat arra sarkallj(uk), hogy ne a problémák jegyében gondolkozzanak, hanem a cikkeket helyezzék előtérbe [...] csak olyan témát válasszanak, amikből publikációk születhetnek".

Szent-Györgyi a legkevésbé sem anarchista, szigorúan érték- és teljesítményközpontú, de a teljesítmény-értékrendje központjában a kutató által vizsgált tudományos problémakör mélysége, újdonsága és eredetisége áll. A tudományos kutatás különböző szintjeiben gondolkozik. Napjaink egyik legforróbb (ál)problémája az alap- és alkalmazott kutatás közötti (ál)ellentét. Szent-Györgyi a valódi különbséget az időben látja: „,...̈sszes jelenlegi örömünk és kényelmünk - legyen szó az elektromosságról, az atomenergiáról, a rádióról, a televízióról vagy a holdrepülésről - mind egy ideig látszólag »használhatatlan« alapismeret volt [...] a »magas szintü tudományt« el lehet hagyni minden azonnali következmény nélkül, de egy vagy két évtizeden belül a fejlödés leállna; az ipar... elavulna."

A legkevésbé sem vitatja az alkalmazott tudomány szerepét és jelentőségét, de ebben is eltérő szinteket, megközelítéseket lát. A tudomány „lehet egy foglalko- 
zás, mint a többi - egy módszer bármilyen probléma megoldására”. De ezt élesen elkülöníti ,a tudomány egy magasabb, müvészi szintjétől”. „Az első segít megoldani mindennapi problémáinkat [...] a második elősegíti ...a jövőt."

Minden kutatással foglalkozó tudja, hogy a kutatás középpontjában az új megfigyelés áll. Az új megfigyelésekhez szükséges kutatómunkához viszont feltételek szükségesek, amelyeket a kutatónak kell megteremtenie elnyert sikeres kutatási pályázatokkal. Így érthető, hogy a szerzőt ez is nagyon foglalkoztatta. Öszinte vallomásában leírja, hogy a kutatási pályázatok írása, ,gyötrelemmel töltötte el az egész tudományos élet(ét)”. „Ha már előre tudjuk, hogy mit fogunk csinálni vagy akár azt, hogy ott mit fogunk találni, akkor az egyáltalán nem kutatás: az csak egy valamiféle tiszteletre méltó foglalkozás.” „Én mindig próbálom az igazat mondani, de egész életemben a kutatási tervek minden egyes lapját hazugságokkal kellett megtöltenem...” „Valójában a kutatási pályázat nem jó mérce.”

A tudomány és a müvészet közti kapcsolat természetesen több szempontból is foglalkoztatta. Gondolatai középpontjában az alkotás lélektana áll. ,...nagyon ritkán fordult elö, hogy valamilyen probléma esetén a válaszra tudatos gondolkodással jöttem volna rá [...] úgy gondolom, hogy egyfajta koncentráció és lelkesedés nélkülözhetetlen mind a müvészetben, mind a tudományban.” „A kreatív tudósnak vagy müvésznek muszáj megtapasztalnia az alkotás örömét azáltal, hogy létrehoz valamit, valami újat, ami eddig nem létezett, bármilyen kicsi is legyen az. Ezen felül szükséges egyfajta alkotói kényszer is..."

„Joggal mondják, hogy »aki nyugodtan ül a babérjain, az bizonyára rossz helyen viseli azokat«. Mindez érdekes, de valójában cseppet sem kellemes. Az alkotói foglalkozás sohasem jár a fájdalom gyötrelme nélkül."

Szent-Györgyi arra is kitér, ,hogy mennyire számítanak a másodlagos motivációk”. Ezek között a hiúságot, az elismerés utáni vágyakozást, a hasznosság kívánságát és a társadalmi, pénzügyi sikert emeli ki. „Ha egy hallgató odajön hozzám és azt mondja, hogy tudományos munkával szeretne foglalkozni annak érdekében, hogy hasznára váljon az emberiségnek, és enyhítse az emberi szenvedést, változatlanul azt tanácsolnám neki, hogy foglalkozzon inkább jótékonykodással. A tudomány egoistákat követel, borzasztóan önző egoistákat, akik saját örömüket és elégedettségüket keresik, de ezt csak a természet rejtélyeinek megfejtésében találják meg." Ez a gondolatkör többször is felbukkan.

A tudományos kommunikációról is nagyon őszintén és önkritikusan ír. Ez azért is meglepő, mert Szent-Györgyi szellemesen, könnyed, laza stílusban, de nagyon pontosan fogalmaz. Egy Nobel-díjas fiziológust, George Waldot idézi: „Ez a munkád olyan könnyedre sikeredett, hogy biztos szörnyen izzadhattál.”

Szent-Györgyi többször is leszögezte különböző müveiben, hogy ,tudja, mit jelent történelmi időkben élni”. Nehezen vitatható, hogy fordulatokban bővelkedő, a politikával többször kapcsolatba kerülö életét a történelmi viharok jelentősen befolyásolták. Az a humanista, higgadt, letisztult, önkritikus látásmód, ahogy 
ennek tanulságait egyszerre humorral és elkötelezettséggel összefoglalja, nagyon is aktuális a ma embere számára.

(A legendás tudós Szent-Györgyi Albert önéletrajzi értekezései, szerkesztette, forditotta és jegyzetelte Tasiné Csúcs Ildikó és Tasi Domonkos Attila. Szeged: Goodwill Pharma az Egészségért Alapitvány, 2017)

Mandl József

az MTA rendes tagja, professor emeritus, Semmelweis Egyetem 